\title{
Antioxidant and anti-inflammatory activities of winery wastes seeds of Vitis labrusca
}

\author{
Atividade antioxidante e anti-inflamatória de sementes de resíduos de vinificação de Vitis labrusca
}

\author{
Gustavo Scola $^{\mathrm{I}}$ Virginia Demarchi Kappel ${ }^{\mathrm{II}}$ José Claudio Fonseca Moreira $^{\mathrm{III}}$ Felipe Dal-Pizzol ${ }^{\mathrm{IV}}$ \\ Mirian Salvador ${ }^{\mathrm{I}}$
}

\begin{abstract}
There are many studies about the biological activities of Vitis vinifera grape seeds, which are rich in phenolic compounds, known by their several health beneficial effects. However, until now there is no data about biological activities of the seeds of V. labrusca, specie found in South and North America. Every year, the global wine production (around 260 million hL) generates about 19.5 million ton of wastes, which are usually discarded in the environment. The aim of this research was to evaluate the antioxidant and anti-inflammatory activities of aqueous extracts of seeds from wine wastes of Vitis labrusca (cv. 'Bordo' and 'Isabella'). Both extracts showed significant antioxidant and anti-inflammatory activities, which are positively correlated with total phenolic content, suggesting that these compounds might be the major contributors to the biological activity of these extracts. These results indicate that water extraction from winery wastes is an option to obtain phenolic compounds with antioxidant and anti-inflammatory activities helping to maintain environmental balance.
\end{abstract}

Key words: V. labrusca, winery wastes, antioxidant, antiinflammatory.

\section{RESUMO}

Apesar de existirem vários estudos sobre a atividade biológica de sementes de uva de Vitis vinifera, ricas em compostos fenólicos com reconhecidos efeitos benéficos à saúde, não existem, até o momento, dados a respeito da atividade biológica de sementes de V. labrusca, espécie amplamente encontrada na América do Sul e do Norte. A cada ano, a produção mundial de vinho (cerca de 260 milhões de $h L)$ gera, aproximadamente, 19,5 milhões de toneladas de resíduos, usualmente descartados no meio ambiente. Em vista disso, o objetivo deste estudo foi avaliar as atividades antioxidante e anti-inflamatória de extratos aquosos de sementes de resíduos de vinificação de V. labrusca (cv. 'Bordo' e 'Isabel'). $O s$ resultados mostraram que ambos os extratos apresentam significante atividade antioxidante e anti-inflamatória, as quais apresentam correlação positiva com o conteúdo de compostos fenólicos dos extratos, sugerindo que estes podem contribuir, significativamente, para a atividade biológica observada. Estes resultados mostram que é possível obter compostos fenólicos com atividades antioxidante e anti-inflamatória utilizando extração aquosa, além de contribuir com o equilíbrio do meio ambiente.

Palavras-chave: V. labrusca, resíduos de vinificação, antioxidante, anti-inflamatório.

\section{INTRODUCTION}

There are several studies about the biological activities of Vitis vinifera grape seed extracts (for review see XIA et al., 2010). These studies using organic solvents (TORRES et al., 2002; XIA et al., 2010) have limited use due to the high cost of the extraction processes. The extraction of phenolic compounds with non-organic solvents is of interest mainly to the pharmaceutical industries, as they are able to minimize pathologies associated with oxidative stress, such as atherosclerosis, diabetes, cancer, inflammatory and neurological diseases (XIA et al., 2010).

Instituto de Biotecnologia, Universidade de Caxias do Sul (UCS), Petrópolis, 95070-560, Caxias do Sul, RS, Brasil.

E-mail: msalvado@ucs.br. Autor para correspondência.

"Departamento de Ciências Farmacêuticas, Universidade Federal de Santa Catarina (UFSC), Florianópolis, SC, Brasil.

IIIDepartamento de Bioquímica, Universidade Federal do Rio Grande do Sul (UFRGS), Porto Alegre, RS, Brasil.

${ }^{\mathrm{IV}}$ Departamento de Medicina, Universidade do Extremo Sul Catarinense (UNESC), Criciuma, SC, Brasil. 
There are few studies about the biological activities of $\boldsymbol{V}$. labrusca specie (RIZZON et al., 2000, VEDANA et al., 2008, DANI et al., 2010), however, until now there are no data about the potential of using $\boldsymbol{V}$. labrusca seeds as a source of biologically active compounds. V. labrusca (mainly the Bordo and Isabella varieties) is the main grape species found in South and North America, and it is widely used to produce wines and grape juices (SOARES DE MOURA et al., 2002; POLLEFEYS \& BOUSQUET, 2003).

Every year, the global wine production (around 260 million $\mathrm{hL}$ ) generates about 19.5 million ton of wastes (OIV, 2010), which are generally used as fertilizer or simply discarded in the environment (TORRES et al., 2002). Although some polyphenols are transferred from the grapes to the wine during vinification, and there is a potential loss of some of these compounds by oxidation during the industrial process, the seed wastes are still good sources of phenolic compounds (TORRES et al., 2002).

This research aimed to assess the antioxidant and anti-inflammatory activities of aqueous extract of $\boldsymbol{V}$. labrusca winery wastes seeds (Bordo and Isabella varieties).

\section{MATERIALS AND METHODS}

Winery wastes of $\boldsymbol{V}$. labrusca (cv. 'Bordo' and 'Isabella') were used in this study. Both varieties were cultivated in the northeastern region of the Serra Gaucha, Rio Grande do Sul, Brazil. Voucher specimens (HUCS31065-31066) were identified by the herbarium of the University of Caxias do Sul, Rio Grande do Sul, Brazil. Seeds were removed from vinification tanks in January 2006, five days after fermentation beginning. They were immediately separated from the remainder of the winery wastes manually, dried in an air oven at $37^{\circ} \mathrm{C}$ and sheltered from light. Grape seeds were pounded in a knife mill (Quimis, Brazil) and the extracts were prepared with $5 \mathrm{~g}$ seeds $100 \mathrm{~mL}^{-1}$ distilled water under reflux $\left(100^{\circ} \mathrm{C}\right)$ for 30 minutes. Extracts were cooled to $25^{\circ} \mathrm{C}$, filtered in (pore size, $0.45 \mu \mathrm{m}$, Millipore Corp., Sao Paulo, Brazil) and freeze-dried at $-60^{\circ} \mathrm{C}, 10^{-1}$ bar. Total phenolic content and the major constituents of these extracts were described in SCOLA et al. (2010) and are shown in table 1. No alkaloids, saponins or terpenoids were found in the extracts.

The antioxidant activity of the $\boldsymbol{V}$. labrusca extracts was assayed by total reactive antioxidant potential (TRAP) (DRESCH et al., 2009), total antioxidant reactivity (TAR) (LISSI et al., 1995), and thiobarbituric acid reactive species (TBARS) (SILVA et al., 2007) assays. TRAP and TAR assays were used to determine the capacity of extracts to trap a flow of water-soluble peroxyl radicals produced at constant rate, through thermal decomposition of AAPH, as previously described. Briefly, the reaction mixture $(4 \mathrm{~mL})$, containing AAPH $(10 \mathrm{mM})$ and luminol $(4 \mathrm{mM})$ in glycine buffer $(0.1 \mathrm{M}), \mathrm{pH} 8.6$, was incubated at $21^{\circ} \mathrm{C}$ for $2 \mathrm{~h}$. AAPH is a source of peroxyl radicals that react with luminol yielding chemiluminescence (CL). The system was calibrated using trolox. The addition of $10 \mu \mathrm{L}$ of the extracts or trolox decreases the CL proportionally to its antioxidant potential. The TRAP profile was obtained by measuring the CL emission in a liquid scintillation counter (Wallac 1409) as counts per minute (CPM). CL intensity was monitored for $50 \mathrm{~min}$ after adding the extracts $\left(2.5 \mu \mathrm{g} \mathrm{mL}^{-1}\right)$ or trolox $(200 \mathrm{nM})$. Results were calculated as area under curve (AUC) of the CL profile and were expressed as percent of inhibition. TAR index was determined by measuring the initial decrease of luminol luminescence calculated as Io/I ratio, where Io is the initial emission of CL (before adding extracts or trolox) and I is the instantaneous CL intensity after adding an aliquot of the sample or the reference compound (trolox).

TBARS were assayed to measure the antioxidant potential of $\boldsymbol{V}$. labrusca extracts against a lipid peroxidation cascade (including different reactive oxygen species, such as peroxyl radicals, superoxide, hydrogen peroxide, and hydroxyl) generated from egg yolk lipid homogenate. Briefly, fresh egg yolk was

Table 1 - Total polyphenol content ( $\mathrm{mg} \mathrm{L}^{-1}$ of catechin equivalent) and major compounds ( $\left.\mathrm{mg} / \mathrm{L}\right)$ in $\boldsymbol{V}$. labrusca grape seed extracts

\begin{tabular}{|c|c|c|c|c|c|c|c|c|c|}
\hline Extracts & $\begin{array}{l}\text { TPC }\left(\mathrm{mg} \mathrm{L}^{-1}\right. \\
\text { CAE) extract }\end{array}$ & Catechin & Epicatechin & Epigallocatechin & $\begin{array}{l}\text { Procyanidin } \\
\text { B1 }\end{array}$ & $\begin{array}{c}\text { Procyanidin } \\
\text { B2 }\end{array}$ & $\begin{array}{c}\text { Procyanidin } \\
\text { B3 }\end{array}$ & $\begin{array}{l}\text { Procyanidin } \\
\text { B4 }\end{array}$ & Gallic acid \\
\hline Bordo & $744.9 \pm 3.1^{\mathrm{a}}$ & $169.3 \pm 0.9^{\mathrm{a}}$ & $168.9 \pm 2.8^{\mathrm{a}}$ & $8.9 \pm 0.1^{\mathrm{a}}$ & $22.4 \pm 0.5^{\mathrm{a}}$ & $19.7 \pm 0.2^{\mathrm{a}}$ & $17.4 \pm 0.1^{\mathrm{a}}$ & $1.8 \pm 0.1^{\mathrm{a}}$ & $12.9 \pm 0.6^{\mathrm{a}}$ \\
\hline Isabella & $353.2 \pm 4.6^{\mathrm{b}}$ & $135.4 \pm 0.9^{b}$ & $112.4 \pm 0.3^{\mathrm{b}}$ & $5.6 \pm 0.1^{b}$ & $8.9 \pm 0.1^{\mathrm{b}}$ & $3.2 \pm 0.7^{\mathrm{b}}$ & $9.7 \pm 0.1^{\mathrm{b}}$ & $1.7 \pm 0.1^{\mathrm{a}}$ & $6.9 \pm 0.1^{\mathrm{b}}$ \\
\hline
\end{tabular}

TPC, total phenolic content; CAE, catechin equivalents. "Different letters indicate significant differences ( $\mathrm{P}=0.05)$. Total phenolic content was measured using Folin-Ciocalteau colorimetric method and major compounds were measured by HPLC. These results are adapted from SCOLA et al. (2010). 
homogenized $(1 \% \mathrm{w} / \mathrm{v})$ in $20 \mathrm{mM}$ phosphate buffer $(\mathrm{pH}$ $7.4), 1 \mathrm{~mL}$ of homogenate was sonicated (10s at potency 4$)$ and then homogenized with $0.1 \mathrm{~mL}$ of extracts $(2.5 \mu \mathrm{g}$ $\mathrm{mL}^{-1}$ ) or positive controls were prepared immediately before use. Lipid peroxidation was induced by adding $0.1 \mathrm{~mL}$ of AAPH solution $(0.12 \mathrm{M})$. AAPH was used as positive control. Reactions were carried out for $30 \mathrm{~min}$ at $37^{\circ} \mathrm{C}$. After cooling, samples $(0.5 \mathrm{~mL})$ were centrifuged with $0.5 \mathrm{~mL}$ of trichloroacetic acid (15\%) at $1200 \mathrm{~g}$ for $10 \mathrm{~min}$. A $0.5 \mathrm{~mL}$ aliquot of supernatant was mixed with $0.5 \mathrm{~mL}$ of $\mathrm{TBA}(0.67 \%)$ and heated at $95^{\circ} \mathrm{C}$ for $30 \mathrm{~min}$. After cooling, sample absorbance was measured using a spectrophotometer at 532nm. Results were expressed as \% of TBARS in relation to the positive control.

The anti-inflammatory activity was assessed in three-months-old Wistar rats (250-350g) from our breeding colony. They were caged in groups of five with free access to food and water and were maintained on a 12-h light-dark cycle (7-19h) at $23 \pm 1^{\circ} \mathrm{C}$. All experimental procedures were performed in accordance with the National Institute of Health Guide for Care and Use of Laboratory Animals (NIH publication, revised 1985) and were carried out according to the regulations of the Brazilian College of Animal Experimentation, COBEA. All efforts were made to minimize animal suffering and to use only the number of animals necessary to produce reliable scientific data. Rats ( $n=6)$ were treated intraperitoneally with saline or $10 \mathrm{mg} \mathrm{kg}^{-1}$ body wt of $\boldsymbol{V}$. labrusca extracts 30 minutes before induction of peritonitis through injection of $0.2 \mathrm{~mL}$ of carrageenan $1 \%$ (PETRONILHO et al., 2010). Four hours after inducing inflammation, animals were euthanized, and pleural exudates from each animal were harvested by washing the pleural cavity with $2 \mathrm{~mL}$ of sterile saline solution for measuring total and differential cell count, lactate dehydrogenase activity (LDH), TNF-alpha levels and total proteins. Total cells in the pleural exudate were enumerated in a Neubauer chamber to obtain total leukocyte counts. LDH and TNF-alpha levels were determined with commercially kits (Labtest Diagnóstica, Brazil and CalbiochemNovabiochem Corporation, USA, respectivelly).Total protein was measured by Lowry method using bovine serum albumin as the standard (LOWRY et al., 1951).

Thiobarbituric acid (TBA), luminol (3aminophthalhydrazide), carrageenan and formalin were purchased from Sigma-Aldrich (St. Louis, MO). 2,2'azobis(2-methylpropionamidine) dihydrochloride (AAPH) and 6-hydroxy-2,5,7,8-tetramethylchroman-2carboxylic acid (trolox) were purchased from Aldrich Chemical (Milwaukee, WI). Acetic acid and glycine were purchased from Nuclear (Diadema, SP, Brazil).
Trichloroacetic acid (TCA) and sodium carbonate were purchased from Synth (Diadema, SP, Brazil). (+)Catechin, (-)-epicatechin, (-)-epigallocatechin, procyanidins B1, B2, B3 and B4 and gallic acid were purchased from Sigma-Aldrich (St. Louis, MO). All other reagents were of analytical grade.

TBARS, TRAP and TAR measurements were performed through four independent tests (in triplicate for each one). Values were averaged and expressed along with the standard deviation. For the anti-inflammatory activity, the means and the standard deviation of data obtained from 6 rats per group were used. Results were subjected to analysis of variance (ANOVA), Tukey's post-hoc test and Pearson's correlation using a SPSS 12.0 software package (SPSS Inc., Chicago, IL).

\section{RESULTS}

Results show that both $\boldsymbol{V}$. labrusca extracts (Bordo and Isabella) have the ability to reduce the luminol-enhanced chemiluminescence, indicating the presence of compounds with peroxyl scavenging properties higher than the trolox activity (Figure 1A). TAR-index results (Figure 1B) show that both extracts are able to scavenge peroxyl radicals, diminishing CL intensity after the addition of the extracts in comparison with trolox. The Bordo extract shows higher antioxidant activity against lipid oxidative damage than the Isabella extract (Figure 1C). In fact, a positive correlation between total phenolic content and TAR index $\left(r^{2}=0.920\right.$, $\mathrm{P} \leq 0.01)$ was found. Interestingly, no correlations were found among specific phenolic compounds and antioxidant activity assessed by TRAP/TAR assays. On the other hand, negative correlations between TBARS levels and specific polyphenols were found, as follow: catechin $\left(\mathrm{r}^{2}=-0.998, \mathrm{P} \leq 0.05\right)$, procyanidin $\mathrm{B} 1$ $\left(r^{2}=-0.999, P \leq 0.01\right)$, procyanidin $\mathrm{B} 2\left(\mathrm{r}^{2}=-0.997, \mathrm{P} \leq 0.01\right)$ and epicatechin $(\mathrm{r} 2=-0.999, \mathrm{P} \leq 0.01)$.

The intraperitoneal injection of $0.2 \mathrm{~mL}$ of $1 \%$ carrageenan into the pleural cavity of rats induced an inflammatory reaction characterized by exudate formation and cell migration, when compared to the control group (saline, Figure 2). Both the Bordo and the Isabella extracts show no significant decrease in the total cell number (Figure 2A) or polymorphonuclear migration (Figure 2B). However, an important decrease in lymphocyte migration to the inflammatory site (Figure 2C) was observed. Treatments with both extracts showed no effects on TNF-alpha levels, LDH, or total proteins in the exudate (data not shown). Positive correlations between the diminished 


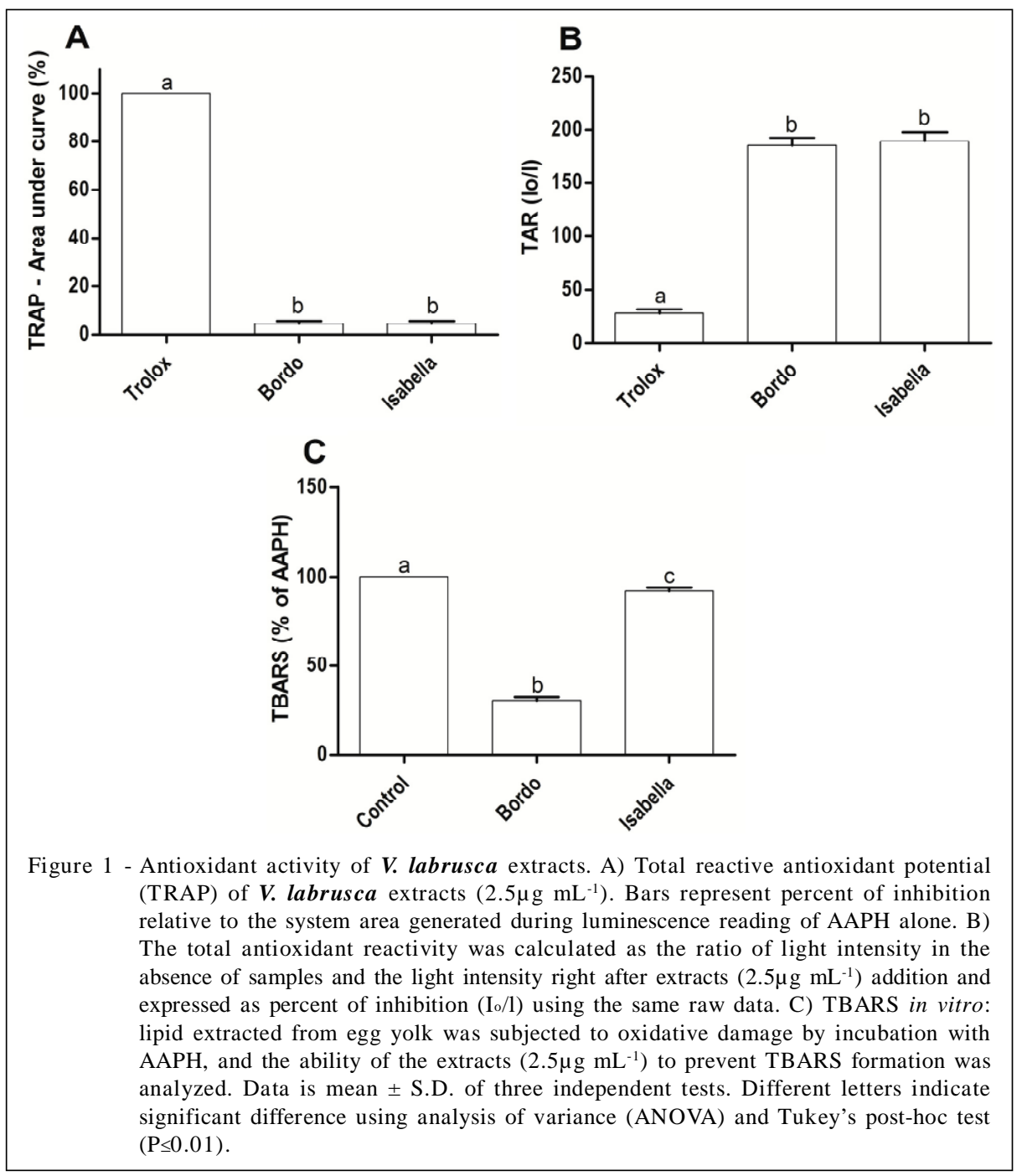

lymphocyte migration levels and specific polyphenols were found: procyanidin B1 $\left(\mathrm{r}^{2}=0.999, \mathrm{P} \leq 0.01\right)$, procyanidin $\mathrm{B} 2\left(\mathrm{r}^{2}=0.976, \mathrm{P} \leq 0.05\right)$, epigallocatechin $\left(r^{2}=0.900, P \leq 0.01\right)$, and epicatechin $\left(r^{2}=0.998, P \leq 0.01\right)$.

\section{DISCUSSION}

Both V. labrusca extracts (Bordo and Isabella) show antioxidant activity assessed by TRAP/TAR (Figure $1 \mathrm{~A}$ and 1B) and TBARS (Figure 1C) assays. The Bordo extract showed higher potential to avoid oxidative damage to lipids, measured by TBARS (Figure 1C), and higher polyphenol content than the Isabella extract (Table 1). Several studies demonstrate that $\boldsymbol{V}$. vinifera varieties show important antioxidant activities (for review see XIA et al., 2010). On the other hand, there is only one research about the antioxidant activity of $\boldsymbol{V}$. labrusca leaves (DANI et al., 2010). This is the first research that shows biological activities for $\boldsymbol{V}$. labrusca seeds from winery wastes. It is possible that phenolic compounds might be the major contributors to the biological activities of V. labrusca extracts related in this research. The antioxidative mechanism of phenolic compounds is mainly ascribed to their free radical-scavenging and metal-chelating properties, as well as their effects on cell-signaling pathways and on gene expression (SOOBRATTEE et al., 2005).

Carrageenan is a high-molecular-weight sulfated polysaccharide, which is widely used in pharmacology to induce local inflammation (paw edema and pleurisy) in rats. Carrageenan-induced pleurisy is a well-characterized experimental model of inflammation, which permits the quantification of exudates and cellular migration (PETRONILHO et al., 2010). The administration of carrageenan into the pleural space leads to pleurisy, characterized by an immediate 

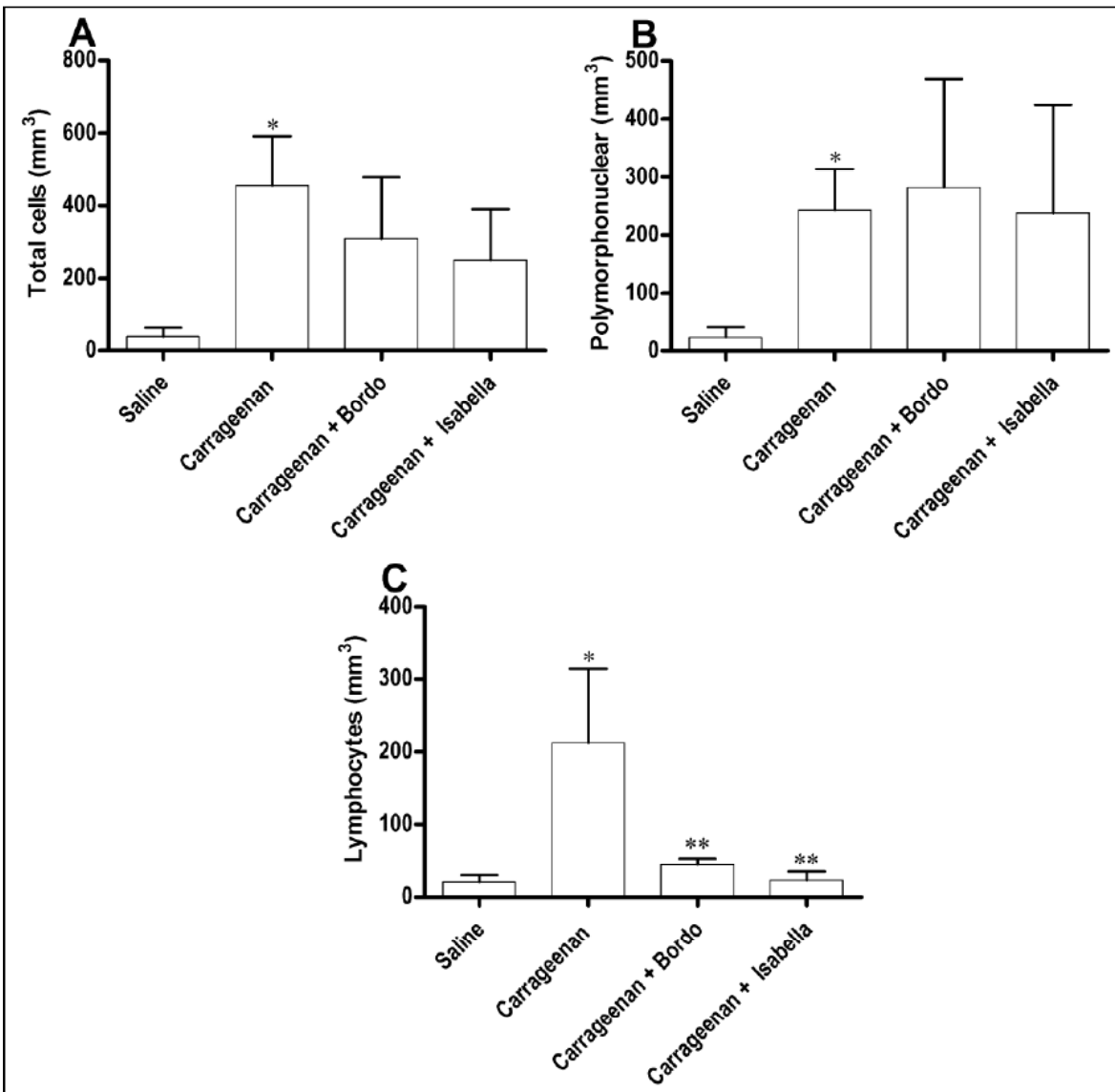

Figure 2 - Effect of the different $\boldsymbol{V}$. labrusca extracts on leukocyte migration into the peritoneal cavity induced by carrageenan in rats. Rats were pre-treated with saline or extracts (10 $\mathrm{mg} \mathrm{kg}^{-1}$ body wt., i.p.) 30 minutes before carrageenan $(2 \mathrm{~mL}$ of $1 \%$ i.p.) induced peritonitis. Cell counts were performed $4 \mathrm{~h}$ after carrageenan injection. Total cells migration (A), polymorphonuclear migration (B) and lymphocytes migration (C) into pleural cavity of rats. Data is mean \pm S.D. * Significant differences from saline $(\mathrm{P} \leq 0.05)$. ** Significant differences from carrageenan $(\mathrm{P} \leq 0.05)$.

polymorphonuclear infiltration. Besides infiltration, pleurisy induced by carrageenan is characterized by the production of neutrophil-derived reactive oxygen species, such as hydrogen peroxide $\left(\mathrm{H}_{2} \mathrm{O}_{2}\right)$, superoxide anion and hydroxyl radical, and neutrophil-derived mediators such as TNF-alpha (SALVEMINI et al., 1996). Evidence from the literature shows that the production of reactive oxygen and nitrogen species occurs at the site of inflammation and contributes to tissue damage (SALVEMINI et al., 1996).

Both Bordo and Isabella extracts presented a significant decrease of lymphocyte migration to the inflammation site (Figure 2C). These data suggest the participation of these compounds in the biological effect observed. Polyphenols are powerful antioxidants and exert anti-inflammatory activities in rats, mice and humans (XIA et al., 2010). Extracts from grape skins and seeds of $\boldsymbol{V}$. rotundifolia inhibited mouse ear inflammation, edema, and polymorphonuclear leukocyte infiltration induced by 12-O-tetradecanoylphorbol 13acetate (BRALLEY et al., 2007).

\section{CONCLUSION}

These data shows that it is possible to obtain aqueous extracts from winery wastes of $\boldsymbol{V}$. labrusca with important antioxidant and anti-inflammatory activities. Besides these biological effects, the use of these wastes could help to maintain environmental balance.

\section{ACKNOWLEDGEMENTS}

The researchers thank the Conselho Nacional de Desenvolvimento Científico e Tecnológico (CNPq), Fundação de Amparo à Pesquisa do Estado do Rio Grande do Sul (FAPERGS), Coordenação de Aperfeiçoamento de Pessoal de Nível Superior (CAPES) and PPGP/UCS for their financial support, and Zanrosso Vineyard for providing the winery wastes. 


\section{REFERENCES}

BRALLEY, E.E. et al. Topical anti-inflammatory activities of Vitis rotundifolia (muscadine grape) extracts in the tetradecanoylphorbol acetate model of ear inflammation. J Med Food, v.10, p.636-642, 2007. Available at: <http:/ /www.liebertonline.com/doi/abs/10.1089/jmf.2006.244>. Accessed: Oct. 08, 2010. doi: 10.1089/jmf.2006.244.

DANI, C. et al. Phenolic content of grapevine leaves (Vitis labrusca var. Bordo) and its neuroprotective effect against peroxide damage. Toxicol in vitro, v.24, p.148153, 2010. Available at: <http://www.sciencedirect.com/ science?_ob=ArticleURL\&_udi=B 6 TCP-4X1 YCF6$1 \&$ \& u s e r $=2614326 \&$ \& c ove r D a t e $=02 /$ $282010 \&$ \&doc $=1 \&$ \&mt $=$ high $\&$ orig $=$ search $\&$ _origin $=\mathrm{s}$ earch \&_sort $=$ d \&_docanchor $=\&$ view $=$ c $\&$ _act $=$ C 000058 $070 \&$ \& version $=1 \&$ \&urlVersion $=0 \&$ \& userid $=2614326 \& \mathrm{md} 5$ $=6$ ec 4 a 7 ce $503 f 5245$ c89baf520554663b\&searchtype $=a>$. Accessed: Jan. 11, 2010. doi: 10.1016/j.tiv.2009.08.006.

DRESCH, M.T. et al. Optimization and validation of an alternative method to evaluate total reactive antioxidant potential. Anal Biochem, v.385, p.107114, 2009. Available at: <http://www.sciencedirect.com/ science?_ob=ArticleURL\&_udi=B6W9V-4TVJNMX$5 \&$ \& s e r $=2614326 \&$ \& over D a t e $=02 / 01 /$ $2009 \&$ \&doc $=1 \&$ \&mt $=$ high $\&$ _orig $=$ search $\&$ _origin $=$ se arch\&_sort $=$ d\&_docanchor $=\&$ view $=$ c \&_acct $=$ C 000058 $070 \&$ \&version $=1 \&$ \&urlVersion $=0 \&$ \&userid $=2614326 \& \mathrm{~m}$ $\mathrm{d} 5=\mathrm{c} 2 \mathrm{c} 6 \mathrm{a} 5 \mathrm{c} 64 \mathrm{ff} 506 \mathrm{e} 45 \mathrm{bfe} 179 \mathrm{be} 6 \mathrm{cbcbb} 0 \&$ searchtype $=\mathrm{a}>$. Accessed: Sept. 29, 2010. doi: 10.1016/ j.ab.2008.10.036.

LISSI, E. et al. Evaluation of total antioxidant potential (TRAP) and total antioxidant reactivity from luminolenhanced chemiluminescence measurements. Free Radic Biol Med, v. 18, p.153-158, 1995. Available at: <http:/ / w w w. $\mathrm{s}$ c i e $\mathrm{n}$ c e d i $\mathrm{r}$ e $\mathrm{c}$ t. science?_ob=ArticleURL\&_udi=B6T38-3 Y6PRWS$15 \&$ _ u s e r $=2614326 \&$ _ c over D a t e $=02 / 28 /$ $1995 \&$ \&_rdoc $=1 \&$ \&mt $=$ high \&_orig $=$ search \&_origin $=$ searc h\&_sort $=$ d\&_docanchor $=\&$ view $=c \&$ _acct $=$ C000058070 \&_version $=1$ \&_urlVersion $=0 \&$ \& userid $=2614326 \& \mathrm{md} 5=23$ f7 674305 ecb1d69e2dfd01d2f6dcd $2 \&$ searchtype $=a>$. Accessed: Jun. 25, 2006. doi: 10.1016/08915849(94)00117-3.

LOWRY, O.H. et al. Protein measurement with the Folin phenol reagent. J Biol Chem, v.193, p.265-275, 1951. Available at: <http://www.jbc.org/content/193/1/265.long>. Accessed: Jan. 11, 2011.

OIV, N.O.T.W.S.M. Organisation International de la Vigne et du Vin, 2010. Available at: <http://www.oiv.org/uk/accueil/ index.php>. Accessed: Apr. 20, 2010.

PETRONILHO, F. et al. Protective effect of gastrin-releasing peptide receptor antagonist in carrageenan-induced pleural inflammation in rats. Inflamm Res, v.59, p.783-789, 2010. Available at: <http:// www.springerlink.com/content/1277232kj3620753/>. Accessed: Oct. 01, 2010. doi: 10.1007/s00011-010-0190-8.

POLLEFEYS, P.; BOUSQUET, J. Molecular genetic diversity of the French-American grapevine hybrids cultivated in North
America. Genome, v.46, p.1037-1048, 2003. Available at: <http://article.pubs.nrc-cnrc.gc.ca/ppv/RPViewDoc?issn=0831$2796 \&$ volume $=46 \&$ issue $=6 \&$ startPage $=1037>$. Accessed: Oct. 01, 2010. doi: 10.1139/G03-076.

RIZZON, L.A. et al. Avaliação da uva cv. Isabel para a elaboração de vinho tinto. Ciênc Tecnol Aliment, v.20, n.1, 2000. Available at: $<$ http://www.scielo.br/scielo.php?script=sci_arttext\&pid=S0101$20612000000100022 \& \operatorname{lng}=e n \& n r m=i s o>$. Accessed: Jan. 11, 2011. doi: $10.1590 / \mathrm{S} 0101-20612000000100022$.

SALVEMINI, D. et al. Nitric oxide: a key mediator in the early and late phase of carrageenan-induced rat paw inflammation. $\mathbf{B r}$ J Pharmacol, v.118, p.829-38, 1996. Available at: <http:// www.ncbi.nlm.nih.gov/pmc/articles/PMC $1909531 /$ ?tool=pubmed $>$. Accessed: Sept. 20, 2010. doi: 0007-1188/96.

SCOLA, G. et al. Flavan-3-ol compounds from wine wastes with in vitro and in vivo antioxidant activity. Nutrients, v.2, p.1048-1059, 2010. Available at: <http://www.mdpi.com/20726643/2/10/1048/>. Accessed: Nov. 04, 2010. doi: 10.3390/ nu 2101048 .

SILVA, E.G. et al. Antioxidant activities and free radical scavenging potential of Bauhinia microstachya (RADDI) MACBR. (Caesalpinaceae) extracts linked to their polyphenol content. Biol Pharm Bull, v.30, p.1488-1496, 2007. Available at: <http://www.jstage.jst.go.jp/article/bpb/30/8/30_1488/_article>. Accessed: Aug. 08, 2009. doi: 0918-6158.

SOARES DE MOURA, R. et al. Antihypertensive, vasodilator and antioxidant effects of a vinifera grape skin extract. J Pharm Pharmacol, v.54, p.1515-1520, 2002. Available at: <http:// onlinelibrary.wiley.com/doi/10.1211/002235702153/abstract > Accessed: Oct. 01, 2010. doi: 10.1211/002235702153.

SOOBRATTEE, M. et al. Phenolics as potential antioxidant therapeutic agents: mechanism and actions. Mol Mech Mutagen, v.579, p.200-213, 2005. Availabe at: <http:// w w w. $\mathrm{s}$ c i e $\mathrm{n}$ c e d i $\mathrm{r}$ e $\mathrm{c}$ t. science?_ob=ArticleURL\&_udi=B6T2C-4GYP0KG$1 \&$ _ u s e r $=2614326 \&$ _ c over D a t e $=11 / 11 /$ $2005 \&$ \&doc $=1 \&$ fmt $=$ high \&_orig $=$ search\&_origin $=$ search $\&$ _s or $\mathrm{t}=\mathrm{d} \&$ _docanchor $=\&$ view $=$ c $\&$ _acct $=\mathrm{C} 000058070 \&$ _versi on $=1 \&$ _urlVersion $=0 \&$ \&userid $=2614326 \&$ md5=be $42 \mathrm{~b} 015 \mathrm{a} 4102398$ 1b6ba63e2643e50c\&searchtype=a>. Accessed: Sept. 22, 2010. doi: 10.1016/j.mrfmmm.2005.03.023.

TORRES, J.L. et al. Valorization of grape (Vitis vinifera) byproducts. Antioxidant and biological properties of polyphenolic fractions differing in procyanidin composition and flavonol content. J Agric Food Chem, v.50, p.75487555, 2002. Available at: <http://pubs.acs.org/doi/abs/10.1021/ jf025868i>. Accessed: Aug. 11, 2010. doi: 10.1021/jf025868i.

VEDANA, M.I.S. et al. Efeito do processamento na atividade antioxidante de uva. Alim Nutr, v.19, n.2, p.159-165, 2008. Available at: <http://200.145.71.150/seer/index.php/alimentos/ article/view/229/224>. Accessed: Jan. 11, 2011.

XIA, E.Q. et al. Biological activities of polyphenols from grapes. Int J Mol Sci, v.11, p.622-646, 2010. Available at: <http://www.ncbi.nlm.nih.gov/pmc/articles/PMC2852857/ ?tool=pubmed>. Accessed: Mar. 28, 2010. doi: 10.3390/ ijms 11020622 . 